\title{
CHLORAMPHENICOL RESISTANCE IN ESCHERICHIA COLI
}

\author{
H. Williams Smith \\ Houghton Poultry Research Station, Houghton, Huntingdon
}

ONE consequence of the discovery that much of the antibiotic resistance of enterobacteria is transmissible has been concern about the chloramphenicolresistance status of the non-pathogenic Escherichia coli that inhabit the alimentary tract of man and domestic animals. This is principally because of the possibility that such resistance might ultimately be transmitted to Salmonella typhi and so limit the usefulness of chloramphenicol in the treatment of typhoid fever.

To demonstrate the transfer of $\mathrm{R}$ factors in vivo requires the use of donor and recipient organisms that not only colonise the alimentary tract well but that transfer the factors from one to the other at a high rate in vitro (Smith, 1970). In most in-vitro studies, $E$. coli strain $\mathrm{K} 12 \mathrm{~F}$ - is employed to determine whether the antibiotic resistance possessed by strains of enterobacteria is transmissible; whether the results so obtained can be taken as an indication of the extent and rate at which the $\mathrm{R}$ factors involved would be transmitted to other strains is questionable. In view of this and of the importance of transmissible chloramphenicol resistance, it was decided to compare strain $\mathrm{K} 12 \mathrm{~F}$ - with a number of pathogenic and non-pathogenic enterobacteria in regard to their ability to receive $\mathrm{R}$ factors from a collection of strains of $E$. coli that were chloramphenicol-resistant.

\section{MATERIALS AND METHODS}

Chloramphenicol-resistant strains of Escherichia coli. Of these, 400 had been isolated from the faeces of domestic animals, principally calves, kept on different premises and 280 had been isolated from different specimens of human sewage.

Potential recipient strains. These were nalidixic acid-resistant mutants (nal $\left.{ }^{\mathrm{r}}\right)$, prepared in the laboratory by the method of Smith and Gyles (1970) from ten fully antibiotic-sensitive strains. These were Salmonella typhimurium of phage-type 29, Salm. typhi $\mathrm{Vi}^{+}$, Salm. heidelberg, Shigella flexneri, Sh. sonnei, two enteropathogenic strains of E. coli of serotype $\mathrm{O} 26: \mathrm{K} 60: \mathrm{H}$ - and $\mathrm{O} 55: \mathrm{K} 59: \mathrm{H} 6$ and two untyped non-pathogenic strains of this organism that had been isolated from the faeces of healthy human beings, nos. 124 and 126 . Of these ten strains, only one, $E$. coli no. 124 , was found to possess a transfer factor.

Antibiotic sensitivity tests. These were performed by the disk-diffusion method used by Smith (1970). The minimum inhibitory concentration of chloramphenicol for different strains of $E$. coli was determined by the method of Smith (1966).

The identification of strains possessing transfer factors only or resistance determinants only. This was achieved by the mobilisation test of Anderson (1965), as described by Smith and Linggood (1970).

Determination of degree of transmission of chloramphenicol resistance. Nutrient Broth

Received 6 Nov. 1972; accepted 2 Jan. 1973.

J. MED. MICROBIOL.-VOL. 6 (1973) 
(Oxoid no. 2) in 10-ml amounts was seeded with $0.02 \mathrm{ml}$ of a broth culture of a prospective donor strain and an equal amount of a similar culture of a nal ${ }^{r}$ prospective recipient strain. The mixed culture was incubated in a waterbath at $37^{\circ} \mathrm{C}$ for $24 \mathrm{hr}$ and the numbers of organisms that had acquired the chloramphenicol $\mathrm{R}$ factor from the donor strain assessed by performing viable counts on MacConkey agar containing $20 \mu \mathrm{g}$ per ml each of sodium nalidixate and of chloramphenicol. In the experiments in which $E$. coli strains $\mathrm{K}_{12} \mathrm{~F}^{-}$, H124 and H126 and Salm. typhimurium were recipients, the counting method employed was that of Miles and Misra (Miles, Misra and Irwin, 1938), the counts being duplicated on MacConkey medium containing sodium nalidixate only so that the total number of prospective recipient organisms present could also be assessed. In the experiments in which the other prospective recipients were used, the number of organisms that had acquired the

\section{TABLE I}

Antibiotic-resistance patterns of 670 strains of Escherichia coli selected because they were resistant to chloramphenicol

\begin{tabular}{|c|c|c|c|}
\hline $\begin{array}{l}\text { Resistance } \\
\text { pattern }\end{array}$ & $\begin{array}{l}\text { Percentage } \\
\text { of strains }\end{array}$ & $\begin{array}{l}\text { Resistance } \\
\text { pattern }\end{array}$ & $\begin{array}{l}\text { Percentage } \\
\text { of strains }\end{array}$ \\
\hline $\begin{array}{l}\text { A S SuT C } \\
\text { S SuTC } \\
\text { A S Su T C } \\
\text { S Su T T C } \\
\text { S Su C } \\
\text { A S Su C } \\
\text { A S Su T T F } \\
\text { A T C } \\
\text { A S T C F } \\
\text { S SuT C F } \\
\text { A S Su N C }\end{array}$ & $\begin{array}{r}37.4 \\
16.2 \\
11.9 \\
9.5 \\
7.9 \\
4.9 \\
2.5 \\
2.2 \\
1.4 \\
1.4 \\
1.0\end{array}$ & $\begin{array}{l}\text { S Su N C } \\
\text { S Su C F } \\
\text { A C } \\
\text { A S C } \\
\text { S Su T C F } \\
\text { A S Su C F } \\
\text { A S Su T C Na } \\
\text { A S Su C Na } \\
\text { S T C } \\
\text { A SuC } \\
\text { C }\end{array}$ & $\begin{array}{l}0 \cdot 6 \\
0 \cdot 6 \\
0 \cdot 6 \\
0 \cdot 5 \\
0 \cdot 3 \\
0 \cdot 3 \\
0 \cdot 2 \\
0 \cdot 2 \\
0 \cdot 2 \\
0 \cdot 2 \\
0\end{array}$ \\
\hline
\end{tabular}

$\mathrm{A}=$ Ampicillin $; \mathrm{S}=$ streptomycin; $\mathrm{Su}=$ sulphonamides $; \mathrm{N}=$ neomycin $; \mathrm{T}=$ tetracyclines; $\mathrm{C}=$ chloramphenicol $; \mathrm{F}=$ furazolidone $; \mathrm{Na}=$ nalidixic acid.

chloramphenicol $\mathrm{R}$ factor was assessed by streaking $0.02 \mathrm{ml}$ of the mixed culture, undiluted and diluted 200 times, in a standard manner on the MacConkey medium containing sodium nalidixate and chloramphenicol and comparing the amount of growth that occurred after incubation with that obtained from mixed cultures containing different known concentrations of chloramphenicol-resistant organisms. The total number of prospective recipient organisms in the mixed cultures varied little. When the rate of transfer of chloramphenicol resistance was high, a full count was performed by the Miles and Misra method.

Fertility inhibiting $(f)$ character of $R$ factors. This was assessed by transferring the chloramphenicol $\mathrm{R}$ factor into a $\mathrm{K}_{12} \mathrm{~F}^{+}$strain and then examining for susceptibility to lysis by the F-specific phage MS2 (Davis, Strauss and Sinsheimer, 1961).

\section{RESULTS}

The results of determining the antibiotic-resistance patterns of 670 chloramphenicol-resistant strains of $E$. coli of human or animal origin are shown in table I. None of the strains was resistant to chloramphenicol only; over 66 per cent. of them were resistant to five or more of the eight antibiotics against which they were tested. In all, 97 per cent. were resistant to streptomycin, 96.5 per cent. to sulphonamides, 83.7 per cent. to tetracyclines, 63.3 per cent. to ampicillin, 26.0 per cent. to neomycin, 6.5 per cent. to furazolidone and 0.4 per cent. to sodium nalidixate. Eighteen strains, selected because most 
of them possessed different antibiotic-resistance patterns, were also tested against spectinomycin; 14 of them were resistant. The minimum inhibitory concentration of chloramphenicol for 100 strains representing 17 different antibioticresistance patterns was $400-800 \mu \mathrm{g}$ per $\mathrm{ml}$; the corresponding figure for strains classed by disk tests as chloramphenicol sensitive was $2 \mu \mathrm{g}$ per $\mathrm{ml}$.

There was considerable variation in the extent and the rate of transfer of chloramphenicol resistance from $E$. coli strains of animal origin to three strains of Salmonella, two of Shigella and five of $E$. coli, the latter including two human non-pathogens (nos. 124 and 126) and two enteropathogens (table II). $E$. coli strain $\mathrm{K} 12 \mathrm{~F}^{-}$was the best recipient and the enteropathogenic $E$. coli $\mathrm{O} 55: \mathrm{K} 59: \mathrm{H} 6$ strain the worst. All the E. coli strain K12 organisms

TABLE II

The transfer rate of chloramphenicol resistance from different potential donor strains of Escherichia coli to different potential recipient strains of enterobacteria

\begin{tabular}{|c|c|c|c|c|c|c|c|c|c|}
\hline \multirow{2}{*}{$\begin{array}{l}\text { Potential } \\
\text { recipient } \\
\text { strain }\end{array}$} & \multirow{2}{*}{$\begin{array}{c}\text { Number of } \\
\text { potential } \\
\text { donor strains } \\
\text { with which } \mathrm{i} \\
\text { was tested }\end{array}$} & \multicolumn{8}{|c|}{$\begin{array}{l}\text { Percentage of potential donor strains whose chloramphenicol resistance } \\
\text { was acquired by the following percentage of organisms of the potential } \\
\text { recipient strain* }\end{array}$} \\
\hline & & $>10^{1}$ & $>10^{\circ}$ & $>10^{-1}$ & $>10^{-2}$ & $>10^{-3}$ & $>10^{-4}$ & $>10^{-5}$ & $>10^{-6}$ \\
\hline $\begin{array}{l}\text { E. coli no. } \mathrm{K}^{2} \mathrm{~F}^{-} \\
\text {Salm. heidelberg } \\
\text { Salm. typhi } \mathrm{Vi}^{+} \\
\text {Sh. flexneri } \\
\text { E. coli no. } 124 \\
\text { Sh. sonnei } \\
\text { Salm. typhimurium } \\
\text { E. coli no. } 126 \\
\text { E. coli }\end{array}$ & $\begin{array}{r}400 \\
160 \\
40 \\
40 \\
200 \\
150 \\
400 \\
185 \\
\end{array}$ & $\begin{array}{l}52 \\
10 \\
0 \\
0 \\
3 \\
4 \\
0 \cdot 3 \\
0 \cdot 5 \\
0 \cdot 3\end{array}$ & $\begin{array}{r}67 \\
28 \\
8 \\
15 \\
13 \\
10 \\
4 \\
1\end{array}$ & $\begin{array}{r}73 \\
48 \\
35 \\
33 \\
40 \\
37 \\
11 \\
5\end{array}$ & $\begin{array}{r}77 \\
62 \\
68 \\
45 \\
42 \\
48 \\
18 \\
15 \\
\end{array}$ & $\begin{array}{l}80 \\
68 \\
80 \\
53 \\
55 \\
61 \\
36 \\
33 \\
\end{array}$ & $\begin{array}{l}87 \\
73 \\
93 \\
78 \\
66 \\
67 \\
50 \\
46\end{array}$ & $\begin{array}{l}88 \\
\ldots \\
\ldots \\
\ldots \\
\ldots \\
55\end{array}$ & $\begin{array}{l}96 \\
\ldots \\
\ldots \\
\ldots \\
\ldots \\
\dddot{56}\end{array}$ \\
\hline $\begin{array}{l}\mathrm{O} 26: \mathrm{K} 60: \mathrm{H}- \\
\text { E. coli } \\
\quad 055: \mathrm{K} 59: \mathrm{H} 6\end{array}$ & $\begin{array}{l}375 \\
400\end{array}$ & $\begin{array}{l}0 \cdot 3 \\
0\end{array}$ & $\begin{array}{l}1 \\
0\end{array}$ & $\begin{array}{l}3 \\
1\end{array}$ & $\begin{array}{l}9 \\
1\end{array}$ & $\begin{array}{r}16 \\
1\end{array}$ & $\begin{array}{r}23 \\
3\end{array}$ & $\begin{array}{r}46 \\
7\end{array}$ & $\begin{array}{l}52 \\
13\end{array}$ \\
\hline
\end{tabular}

$*$ = During mixed culture for $24 \mathrm{hr}$ at $37^{\circ} \mathrm{C}$.

$\ldots=$ Insufficient culture examined to detect transfer to less than $10^{-4}$ per cent. of organisms.

appeared to have received the chloramphenicol $R$ factor in the tests with 20 per cent. of the prospective donor strains. The corresponding figure for Salm. heidelberg was 1.5 per cent.; this high transfer rate was not noted in the case of any of the other eight potential recipient strains.

The antibiotic resistance possessed by two of the 16 strains that did not transfer their $\mathrm{R}$ factors to strain $\mathrm{K} 12 \mathrm{~F}$ - could be mobilised by transfer factors $\mathrm{F}$ and $\mathrm{I}$. In seven of ten donor strains studied in more detail, all the $\mathrm{R}$ determinants appeared to be linked. Eight of the ten strains possessed $\mathrm{fi}+$ transfer factors, one an $\mathrm{fi}^{-}$transfer factor and one both kinds of transfer factors.

\section{DisCUSSION}

Because all the 670 apparently unrelated chloramphenicol-resistant strains of Escherichia coli were multi-resistant, the presence of chloramphenicol in 
the alimentary tract might not be essential to favour either their survival in that organ or that of any other strains to which they transfer their $\mathbf{R}$ factors. Any of the other antibiotics to which they were resistant would probably suffice. In fact, those that, unlike chloramphenicol, are excreted in the faeces in high concentration after oral administration would be expected to function better in this respect. This was actually the case in studies on the experimental transfer of $\mathrm{R}$ factors in vivo (Smith, 1970).

The results confirm the well-established usefulness of $E$. coli strain $\mathrm{K} 12 \mathrm{~F}-$ in detecting strains of $E$. coli whose antibiotic resistance is due to $\mathrm{R}$ factors in that all except 16 of 400 of the chloramphenicol-resistant strains transmitted their resistance to it, often at a very high rate. The results with this strain, however, gave little guide as to the rate at which the $\mathbf{R}$ factors would be transmitted to the other strains that were either pathogens or might be concerned in the epidemiology of $\mathrm{R}$ factors. It is important to know this because, in experimental studies, $\mathrm{R}$-factor transfer could usually be detected in vivo only between those combinations of strains that transmitted and received $\mathrm{R}$ factors at a high rate in vitro (Smith, 1970).

\section{SUMMARY}

All of 670 apparently unrelated chloramphenicol-resistant strains of Escherichia coli of human and animal origin were multiply-resistant; over 66 per cent. of them were resistant to five or more antibiotics.

The resistance of 96 per cent. of 400 of the strains could be transmitted, often at a high rate, to $E$. coli strain $\mathrm{K} 12 \mathrm{~F}^{-}$. A lower and variable proportion of the strains transmitted their resistance to nine other enterobacterial strains, principally pathogens; the rate of transmission was much lower than that which occurred to E. coli strain $\mathrm{K} 12 \mathrm{~F}-$.

I am grateful to Dr E. S. Anderson, Mrs Anne Millington and Miss Diane Poulton for assistance in a variety of ways. The expenses of this work were kindly defrayed by a grant from the Medical Research Council.

\section{REFERENCES}

ANDERSON, E. S. 1965. A rapid screening test for transfer factors in drug-sensitive Enterobacteriaceae. Nature, Lond., 208, 1016.

Davis, J. E., Strauss, J. H., JR, ANd Sinsheimer, R. L. 1961. Bacteriophage MS2: another RNA phage. Science, N.Y., 134, 1427.

Miles, A. A., MisRa, S. S., AND IRWIN, J. O. 1938. The estimation of the bactericidal power of the blood. J. Hyg., Camb., 38, 732.

SмITH, H. W. 1966. The incidence of infective drug resistance in strains of Escherichia coli isolated from diseased human beings and domestic animals. J. Hyg., Camb., 64, 465.

SMITH, H. W. 1970. The transfer of antibiotic resistance between strains of enterobacteria in chicken, calves and pigs. J. Med. Microbiol., 3, 165.

SMITH, H. W., AND GYLES, C. L. 1970 . The relationship between different transmissible plasmids introduced by F into the same strain of Escherichia coli K12. J. Gen. Microbiol., 62, 277.

Smith, H. W., and Linggood, Margaret A. 1970. Transfer factors of Escherichia coli with particular regard to their incidence in enteropathogenic strains. J. Gen. Microbiol. 62, 287. 